\title{
Australian Journal of Crop Science \\ Inter-annual analysis of soybean and corn yield in relation to water deficit in a transitional zone between subtropical and tropical climate
}

\author{
Geovanna C. Zaro ${ }^{* 1}$, Paulo H. Caramori ${ }^{\dagger 2}$, Wilian da S. Ricce ${ }^{3}$, Pablo R. Nitsche ${ }^{2}$, Simone S. Werner ${ }^{3}$, \\ Juliandra R. Rosisca ${ }^{1}$, Gisele S. de Aquino ${ }^{1}$, Angela B. F. da Costa ${ }^{4}$ \\ ${ }^{1}$ Londrina State University - UEL, Agricultural Science Center, Londrina-PR, Brazil \\ ${ }^{2}$ Agronomic Institute of Parana - IAPAR, Ecofisiology Section, Londrina-PR, Brazil \\ ${ }^{3}$ Agricultural Research and Rural Extension Enterprise of Santa Catarina - Epagri, Florianópolis-SC, Brazil \\ ${ }^{4}$ Meteorological System of Paraná - SIMEPAR, Curitiba-PR, Brazil
}

*Corresponding author: geoczaro@gmail.com

tSenior author

\begin{abstract}
Biofuels from soybean and corn oil can potentially create new markets in Brazil. The key to a stable biofuel production is the use of high-yielding varieties tolerant to environmental stresses. The inter-annual variability of rainfall caused by large scale meteorological phenomena, such as El Niño-Southern Oscillation and irregular distribution of precipitation has been a major cause of uncertainty in agricultural production in Brazil. The objective of this study was to perform an inter-annual and inter-regional analysis of soybean and corn yield in relation to water deficit in a transitional zone between subtropical and tropical climate in southern Brazil. The study was conducted in the state of Parana $\left(22-26^{\circ} \mathrm{S}\right)$, one of the main soybean and corn producing areas in the country. The state was divided into six regions (Northwest, North, West, Midwest, Southwest, and South), and the year with the highest productivity in each region was used as a reference to calculate the relative yield losses per year. These losses were correlated with the accumulated water deficit between November and January. The relative yield losses of soybean and corn had a nonlinear relationship with water deficit within each region. Based on the market prices of each year, we estimated that the total losses due to water deficit over the nine growing seasons were $\$ 8.36$ and $\$ 2.67$ billion for soybean and corn, respectively. In terms of productivity, the South region showed the highest stability, whereas the Northwest region the lowest stability in response to water deficit. The results show that inter-annual and regional variability of water stress play an important role in soybean and corn productivity in the transition zone between tropical and subtropical climate in southern Brazil.
\end{abstract}

Keywords: water deficit, crop losses, yield, water balance, biofuels.

\section{Introduction}

Fossil fuels are still the main source of energy worldwide; however, their continued use will lead to shortage in the following decades. Moreover, these fuels are responsible for the release of gases, especially $\mathrm{CO}_{2}$, that increase the greenhouse effect (Höök and Tang, 2013). According to the Intergovernmental Panel on Climate Change (IPCC), the projected global warming by the end of the $21^{\text {st }}$ century may vary between $1.7^{\circ} \mathrm{C}$ and $4.8^{\circ} \mathrm{C}$ (IPCC, 2014). To mitigate the impact caused by these changes, scientists pursue clean and renewable alternative energy sources, including biofuels. The key requirements for a stable biofuel production are the existence of highly productive oil crop varieties, cheap prices of the raw material, and a well-defined manufacturing technology for large-scale production. Both soybean and corn meet these requirements and are considered major feedstocks for biofuel production.

Since 1970, Brazil and the United States have focused on bioethanol production using sugarcane and corn (Markevicius et al., 2010; Aytav and Kocar, 2013). The global production of bioethanol in 2015 was 97.2 billion liters, of which $58 \%$ was produced by the US and $28 \%$ by Brazil (AFDC, 2016). The main source for biodiesel production in Brazil is soybean oil. Between January and July $2016,78 \%$ of all the biodiesel produced in Brazil derived from soybean oil, followed by animal fats $(17 \%)$, cottonseed oil $(1 \%)$, and oil discharged after frying (1\%). Approximately 1.72 million tons of soybean oil was used for biodiesel production (ABIOVE, 2016).

The State of Paraná is located in a transitional zone between subtropical and tropical climate and has a great potential to expand the soybean and corn production for biofuels. Precipitation increases from North to South, whereas the opposite trend occurs for evapotranspiration (Caviglione et al., 2000). The State of Paraná is one of the most productive agricultural areas in Brazil, accounting for $2.34 \%$ of the total territory and approximately $20 \%$ of the total agricultural production (SEAB/DERAL, 2015). Soybean is grown in the spring-summer crop season between September and March, whereas corn is grown in the spring- 
summer crop season (September to February) and the autumn-winter crop season (March to July). The annual soybean production was approximately 17 million tons in both 2015 and 2016, whereas the annual corn production was 4.6 and 3.3 million tons in the spring-summer season of 2015 and 2016, respectively (Brazilian Institute of Geography and Statistics - IBGE, 2016). Although the main use of soybean and corn is the production of edible oil, food, and feed, the amount used for ethanol and biodiesel production increases yearly due to the high market demand. Several agricultural cooperatives in the States of Goias and Mato Grosso use corn for producing ethanol during the off-season of sugarcane. In the State of Paraná, corn could be also used for ethanol production in areas with relatively low temperature, which are not suitable for sugarcane cultivation. Rain-fed agriculture is highly affected by the annual and regional climate variability. Although normal precipitation values surpass evapotranspiration during the spring-summer crop season (Caviglione et al., 2000), water deficit is the main cause of yield losses due to interannual variability in the State of Paraná. In the spring-summer season, the most critical periods are between November and January, since soybean is more sensitive to water deficit from sowing to emergence and from flowering to grain filling (Morando et al., 2014), whereas corn during flowering (Bergamaschi et al., 2006; Pegorare et al., 2009; Wagner et al., 2013). In this study, we aimed to analyze the effect of water deficit on soybean and corn yield in a transitional zone between subtropical and tropical climate. Our results might help the government to establish policies for supporting the agricultural production and also assist farmers to predict yield losses due to water deficit and make strategic investment decisions.

\section{Results and discussion}

\section{Soybean and corn yield and climate variability}

Figs. 2 and 3 show the annual soybean and corn yield ( $k g$ ha $\left.{ }^{1}\right)$, respectively, in each of the six regions of the State of Parana. The Northwest region showed the lowest soybean and corn productivity, probably due to the relatively low soil fertility, low precipitation, and high evapotranspiration (Caviglione et al., 2000). Inter-regional differences were more pronounced for corn, suggesting its relatively higher sensitivity to water deficit. These results suggested that the Northwest region might be suitable for other types of crops that are less sensitive to climate variations such as native tree species, perennial crops, and pasture grasses.

The annual and regional yield losses in soybean and corn are presented in Tables 1 and 2, respectively. The 2008/2009 growing season showed the highest production losses throughout the state, averaging $33.5 \%$ for soybean and $40.5 \%$ for corn, followed by the $2011 / 2012$ growing season, averaging $31.7 \%$ for soybean and $18.9 \%$ for corn. The West region showed the highest production losses for soybean, averaging approximately $47 \%$ in both growing seasons (Table 1 ), whereas the Southwest region the highest production losses for corn, averaging $53.3 \%$ in the $2008 / 2009$ growing season and $40 \%$ in the $2011 / 2012$ growing season (Table 2). Both the 2008/2009 and 2011/2012 growing seasons were affected by La Niña, which changed precipitation patterns and prolonged drought conditions, according to the CPC/NCEP/NOAA (2016).

In southern Brazil, El Niño (warm phase) is associated with high rainfall, whereas La Niña (cold phase) with low rainfall (Grimm et al., 1998). In La Niña years, both soybean and corn are negatively affected by the more frequent occurrence of water deficit conditions (Berlato et al., 2005). However, Alberto et al. (2006) reported that water availability is relatively low in the region of Santa Maria, Rio Grande do Sul, even in the neutral phase (neither El Niño, nor La Niña).

Over the eight growing seasons from 2008/2009 to 2015/2016, the highest production losses in soybean occurred in the Northwest region, averaging 17.4\% (Table 1), whereas those in corn occurred in the Southwest region, averaging $20.0 \%$ (Table 2). The average yield losses throughout the state were $12.9 \%$ for soybean and $14.7 \%$ for corn.

\section{Water balance and crop yield}

Fig. 4 presents the water balance in the growing seasons of two selected years with low and high soybean and corn yield. The results in general showed that a relatively low crop productivity was associated with water deficit conditions, whereas a relatively high productivity with adequate water supply conditions. The State of Parana is characterized by relatively stable climatic conditions during the spring-summer season; thus, soybean and corn yield is not affected by other factors besides the water supply. Data collected by the Brazilian Governmental Insurance Agency for Agricultural Crops (PROAGRO) showed that 95\% of the yield losses in Brazil are due to drought or excessive rainfall (Rossetti, 2001). A previous study showed that the corn yield potential was reduced by approximately $90 \%$ when water deficit conditions occurred prior to tassel emergence and lasted until the beginning of grain fill (Nesmith and Ritchie, 1992).

\section{Yield versus water deficit}

Figs. 5 and 6 show the polynomial regressions between the cumulative water deficit from November to January and yield losses in soybean and corn, respectively. Regressions and coefficients were significant at $P<0.05$, indicating that water deficiency might partly explain the annual and regional variations in the State of Parana. The nonlinear model could be explained by the high frequency of events with a relatively low impact on crop productivity, which are interspersed with those with an extreme impact on crop productivity. The State of Parana is located in a climate transitional zone, bounded by the Tropic of Capricorn, where temperature and precipitation are determined by geographic coordinates and highly influenced by El Niño/La Niña (Caviglione et al., 2000; Grimm et al., 1998). Data variability revealed the complex relations between regional productivity and water availability. Although precipitation followed a regional distribution pattern, spatial distribution was highly irregular, especially in the spring/summer, due to the high occurrence of convective rainfall. Additionally, data variability was caused by inter-regional differences in sowing and harvest dates. Despite the high level of variability, correlation results were in agreement with those reported in 
Table 1. Soybean yield losses in six regions (Northwest, North, West, Midwest, Southwest, and South) of the State of Parana, Brazil, in the 2007/2008-2015/2016 growing seasons.

\begin{tabular}{|c|c|c|c|c|c|c|c|}
\hline \multirow[t]{2}{*}{ Growing season } & \multicolumn{6}{|c|}{ Region } & \multirow[t]{2}{*}{ Mean } \\
\hline & NW & $\mathrm{N}$ & W & MW & sW & $S$ & \\
\hline $2007 / 2008$ & 0.204 & 0.152 & 0.092 & 0.093 & 0.213 & 0.144 & 0.150 \\
\hline $2008 / 2009$ & 0.418 & 0.322 & 0.471 & 0.315 & 0.293 & 0.192 & 0.335 \\
\hline $2009 / 2010$ & 0.036 & 0.115 & 0.038 & 0.027 & 0.097 & 0.104 & 0.070 \\
\hline $2010 / 2011$ & 0.000 & 0.000 & 0.035 & 0.001 & 0.000 & 0.012 & 0.008 \\
\hline $2011 / 2012$ & 0.405 & 0.243 & 0.475 & 0.262 & 0.423 & 0.094 & 0.317 \\
\hline $2012 / 2013$ & 0.078 & 0.037 & 0.000 & 0.000 & 0.087 & 0.000 & 0.034 \\
\hline $2013 / 2014$ & 0.177 & 0.314 & 0.021 & 0.059 & 0.113 & 0.112 & 0.135 \\
\hline $2014 / 2015$ & 0.079 & 0.057 & 0.037 & 0.030 & 0.028 & 0.002 & 0.039 \\
\hline $2015 / 2016$ & 0.108 & 0.187 & 0.034 & 0.078 & 0.034 & 0.025 & 0.078 \\
\hline Mean & 0.174 & 0.158 & 0.134 & 0.096 & 0.140 & 0.075 & 0.129 \\
\hline
\end{tabular}

NW, Northwest; N, North; W, West; MW, Midwest; SW, Southwest; S, South

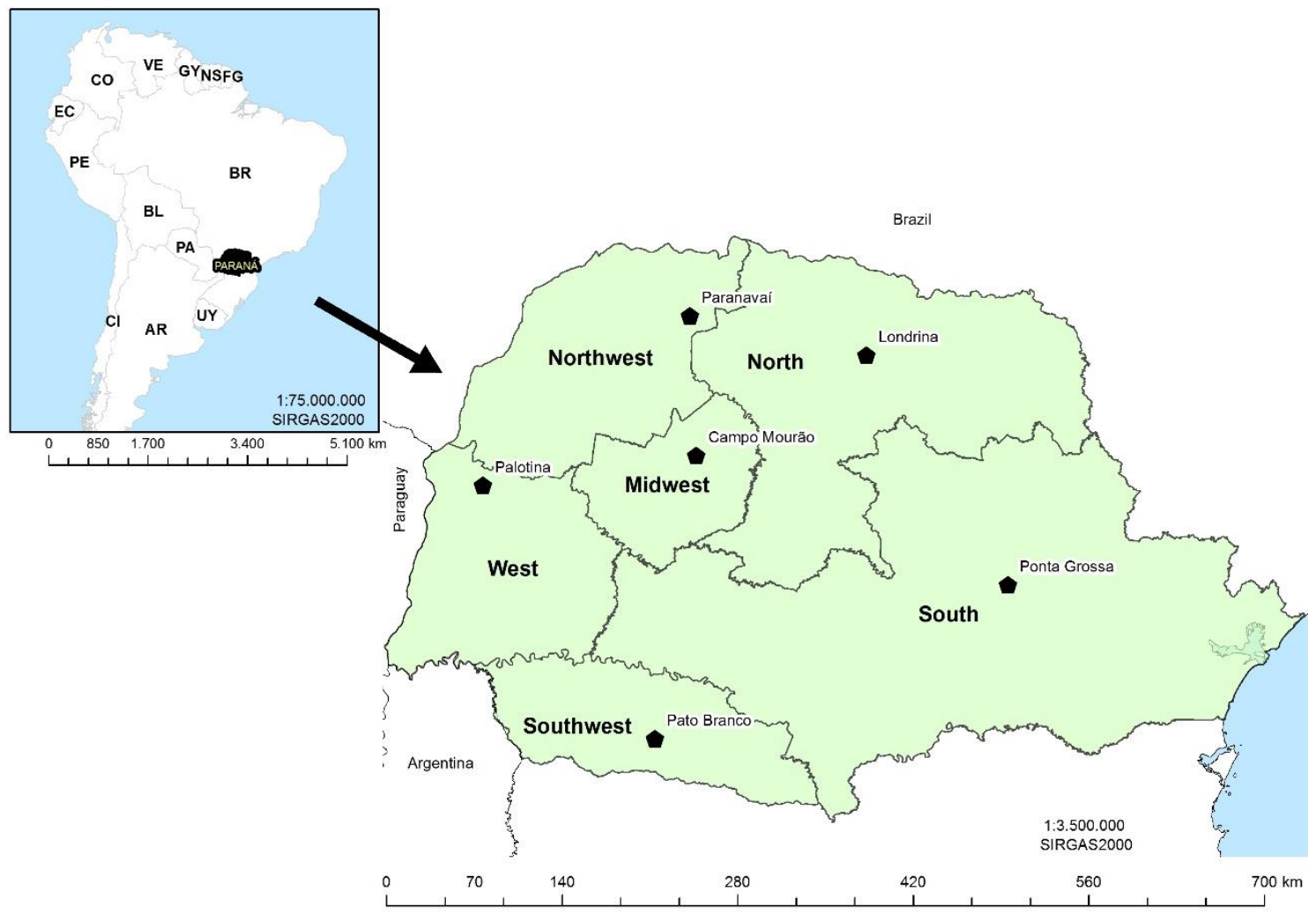

Fig 1. Six regions (Northwest, North, West, Midwest, Southwest, and South) in the State of Paraná, Brazil. Solid dots indicate the city where the weather station is located in each region. 
Table 2. Corn yield losses in six regions (Northwest, North, West, Midwest, Southwest, and South) of the State of Parana, Brazil, in the 2007/2008-2015/2016 growing seasons.

\begin{tabular}{|c|c|c|c|c|c|c|c|}
\hline Growing season & Region & & & & & & Mean \\
\hline & NW & $\mathrm{N}$ & w & MW & SW & $S$ & \\
\hline $2007 / 2008$ & 0.177 & 0.047 & 0.138 & 0.174 & 0.308 & 0.145 & 0.165 \\
\hline $2008 / 2009$ & 0.468 & 0.349 & 0.430 & 0.399 & 0.533 & 0.253 & 0.405 \\
\hline $2009 / 2010$ & 0.128 & 0.066 & 0.082 & 0.097 & 0.150 & 0.071 & 0.099 \\
\hline $2010 / 2011$ & 0.089 & 0.000 & 0.050 & 0.141 & 0.100 & 0.043 & 0.071 \\
\hline $2011 / 2012$ & 0.162 & 0.196 & 0.214 & 0.078 & 0.400 & 0.082 & 0.189 \\
\hline $2012 / 2013$ & 0.000 & 0.045 & 0.062 & 0.000 & 0.108 & 0.000 & 0.036 \\
\hline $2013 / 2014$ & 0.135 & 0.180 & 0.000 & 0.053 & 0.000 & 0.036 & 0.067 \\
\hline $2014 / 2015$ & 0.070 & 0.048 & 0.079 & 0.078 & 0.060 & 0.000 & 0.056 \\
\hline $2015 / 2016$ & 0.237 & 0.080 & 0.133 & 0.144 & 0.144 & 0.075 & 0.136 \\
\hline Mean & 0.163 & 0.112 & 0.132 & 0.129 & 0.200 & 0.143 & 0.147 \\
\hline
\end{tabular}

NW, Northwest; N, North; W, West; MW, Midwest; SW, Southwest; S, South

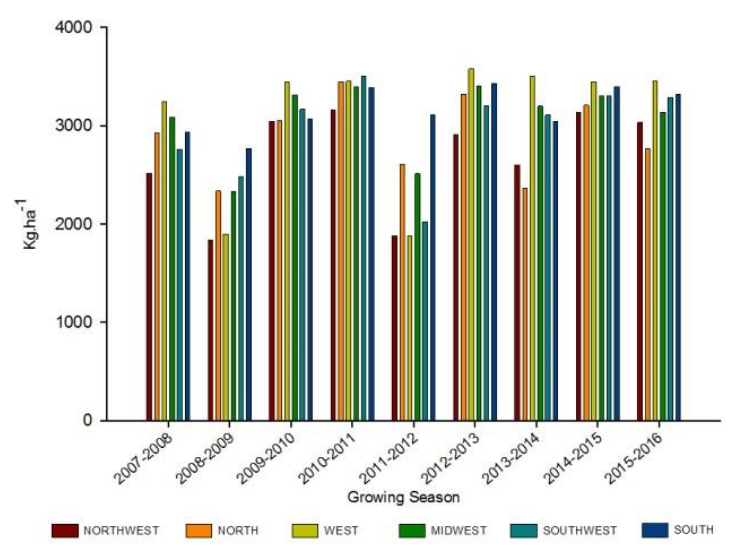

Fig 2. Soybean yield $\left(\mathrm{kg} \mathrm{ha}^{-1}\right)$ in six regions (Northwest, North, West, Midwest, Southwest, and South) of the State of Parana, Brazil, in the 2007/2008-2015/2016 growing seasons. Source: Secretariat of Agriculture and Supply, Department of Rural Economy of Parana (SEAB/DERAL).

Table 3. Monetary losses (million \$) for soybean and corn in six regions (Northwest, North, West, Midwest, Southwest, and South) of the State of Parana, Brazil, in the 2007/2008-2015/2016 growing seasons.

\begin{tabular}{lll}
\hline \multicolumn{1}{c}{ Region } & Soybean & Corn \\
\hline Northwest & $\$ 372.62 \mathrm{M}$ & $\$ 13.54 \mathrm{M}$ \\
\hline North & $\$ 3,157.729 \mathrm{M}$ & $\$ 265.89 \mathrm{M}$ \\
\hline West & $\$ 1,840.23 \mathrm{M}$ & $\$ 224.59 \mathrm{M}$ \\
\hline Midwest & $\$ 817.09 \mathrm{M}$ & $\$ 91.99 \mathrm{M}$ \\
\hline Southwest & $\$ 1,073.05 \mathrm{M}$ & $\$ 697.71 \mathrm{M}$ \\
\hline South & $\$ 1,096.82 \mathrm{M}$ & $\$ 1,379.83 \mathrm{M}$ \\
\hline Total & $\$ 8,357.54 \mathrm{M}$ & $\$ 2,673.55 \mathrm{M}$ \\
\hline
\end{tabular}




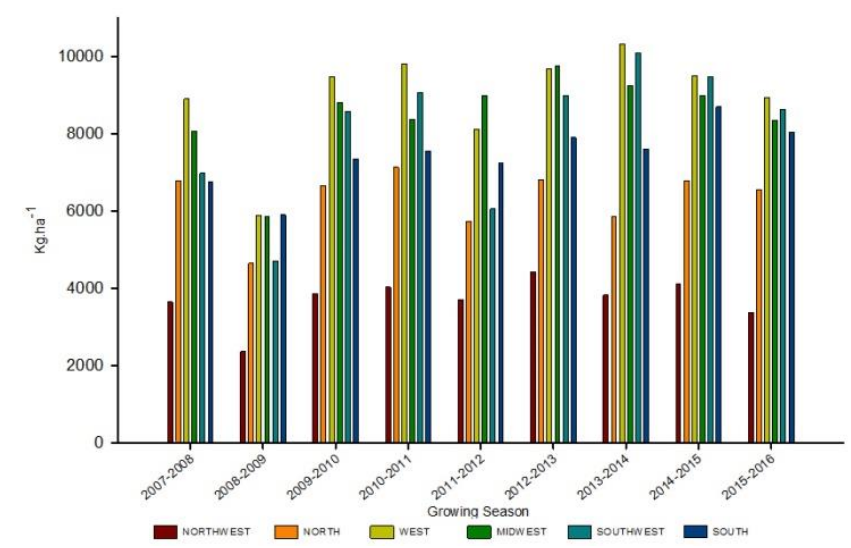

Fig 3. Corn yield $\left(\mathrm{kg} \mathrm{ha}^{-1}\right)$ in six regions (Northwest, North, West, Midwest, Southwest, and South) of the State of Parana, Brazil, in the 2007/2008-2015/2016 growing seasons. Source: Secretariat of Agriculture and Supply, Department of Rural Economy of Parana (SEAB/DERAL).
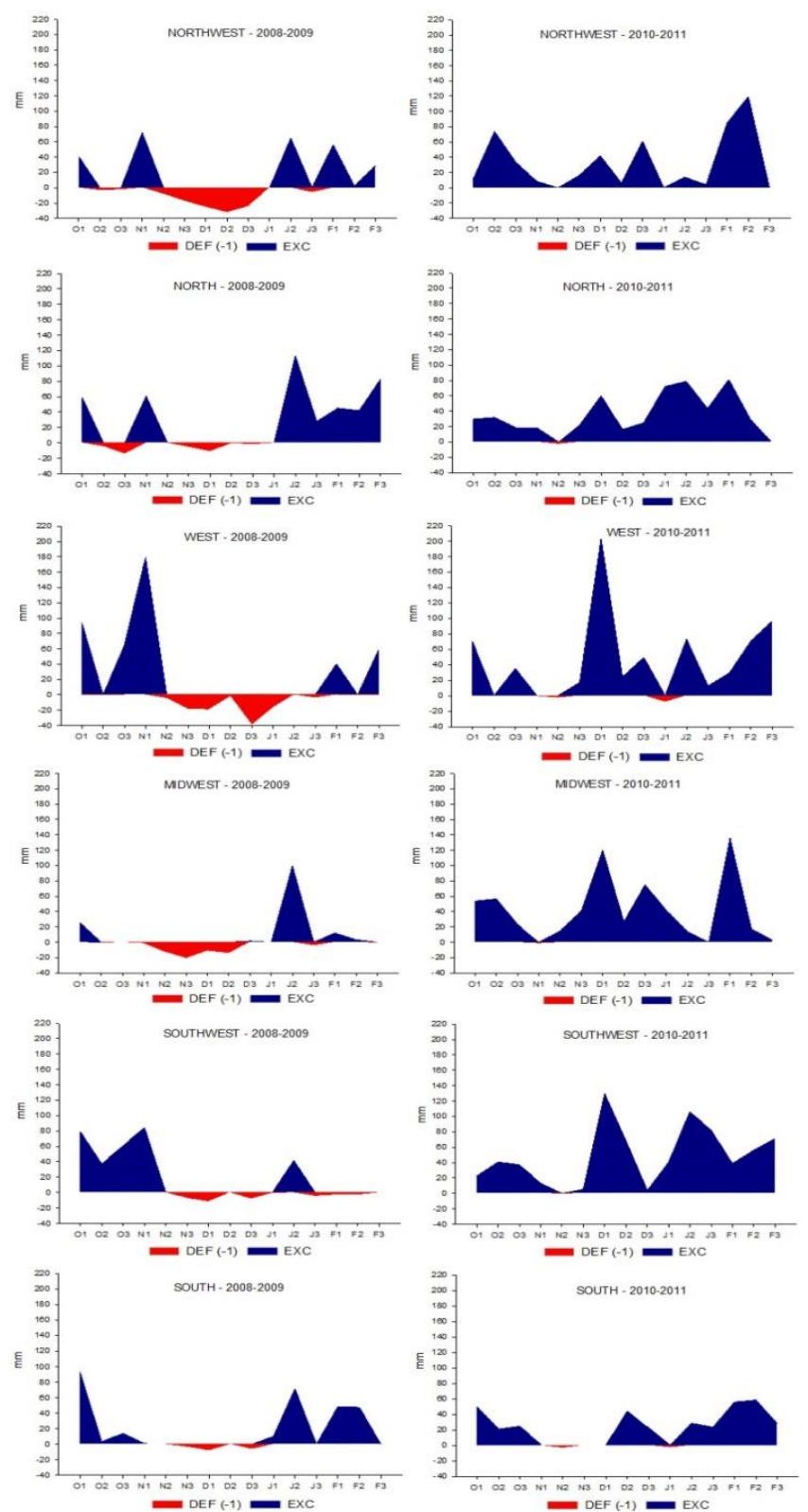

Fig 4. Ten-day water balance during the growing seasons with the low (2008/2009) and high (2010/2011) soybean and corn yield in six regions (Northwest, North, West, Midwest, Southwest, and South) of the State of Parana, Brazil. Def, deficit; Exc, excess. 

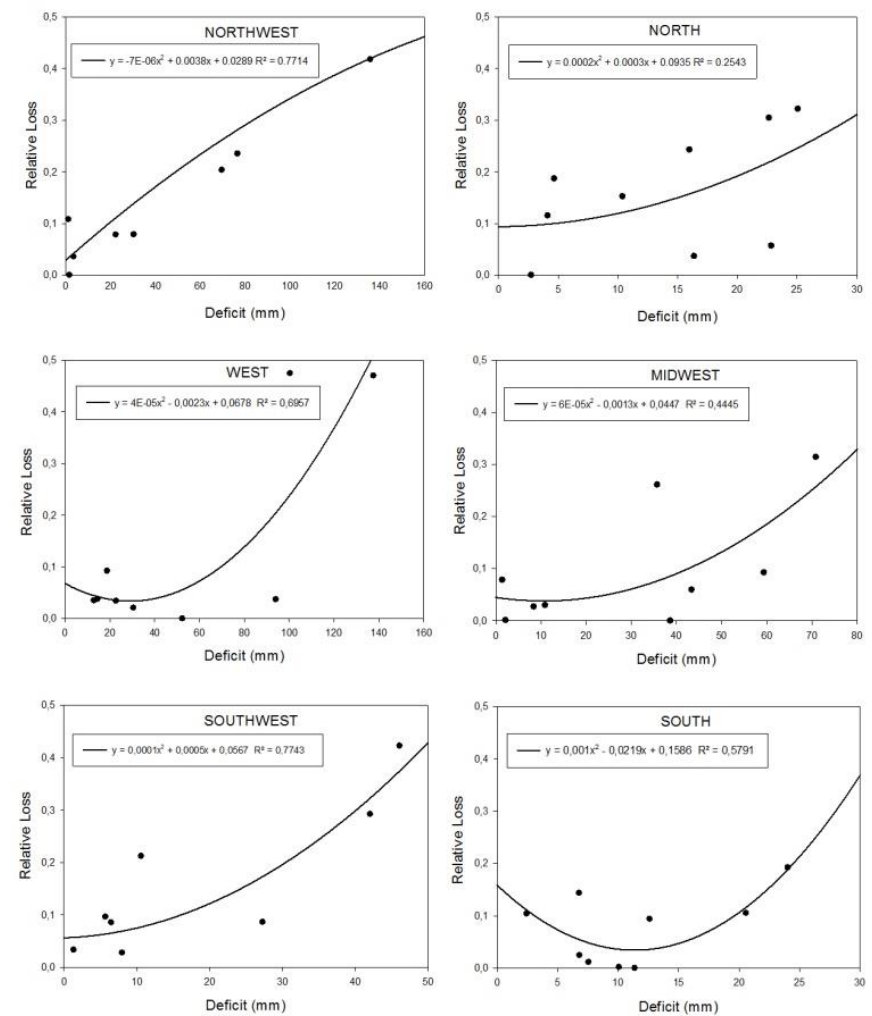

Fig 5. Soybean yield losses related to cumulative water deficit between November and January in six regions (Northwest, North, West, Midwest, Southwest, and South) of the State of Parana, Brazil.
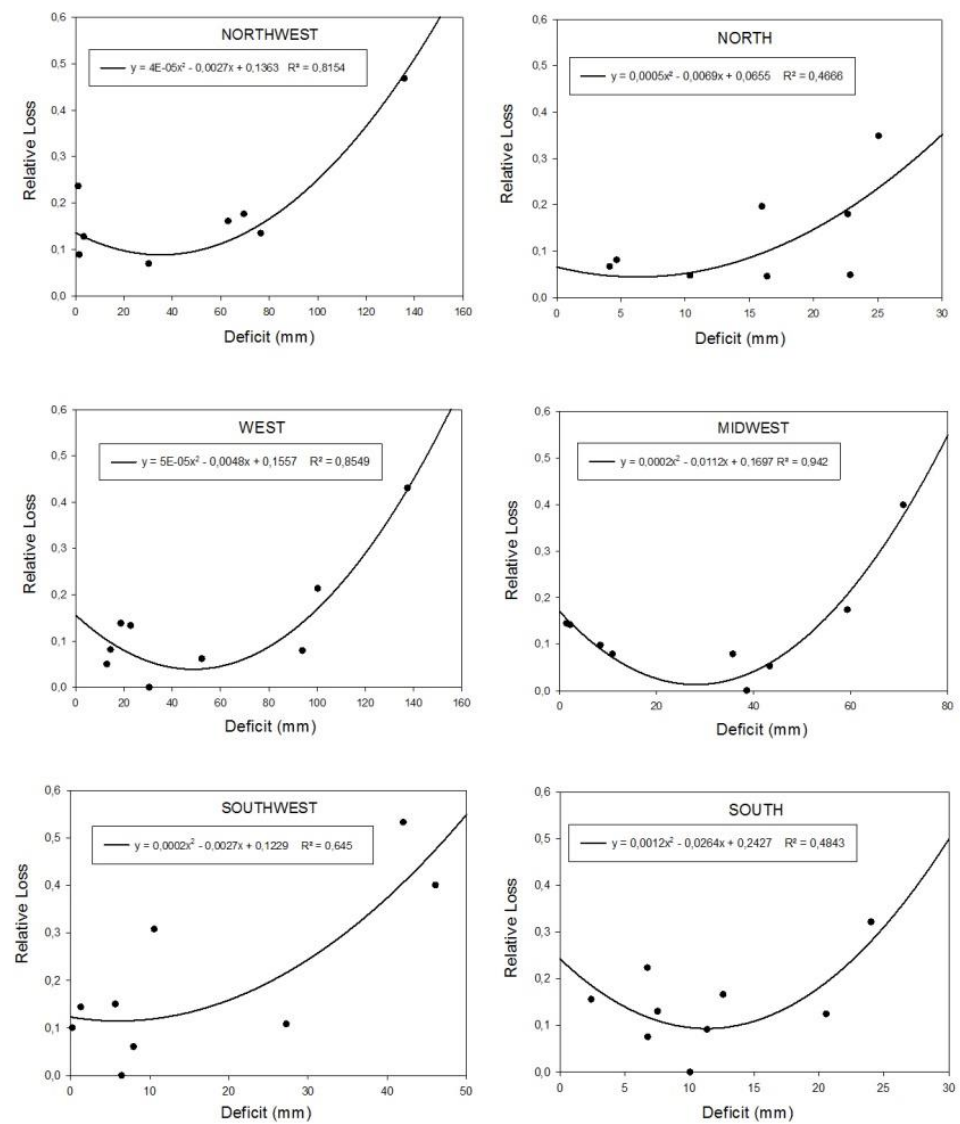

Fig 6. Corn yield losses related to cumulative water deficit between November and January in six regions (Northwest, North, West, Midwest, Southwest, and South) of the State of Parana, Brazil. 
previous studies (Berlato et al., 2005; Bergamaschi et al., 2006).

\section{Monetary loss}

The regional monetary losses estimated based on the soybean and corn yield losses (Tables 1 and 2) are presented in Table 3. The total monetary losses were approximately $\$ 11$ billion for both crops. The North and West regions had the highest economic impact related to soybean yield losses, since they included the largest production areas.

Overall, our analysis revealed the significant impact of water deficit on soybean and corn productivity in the State of Parana and also, the existence of inter-regional differences. Thus, more research is needed to develop drought tolerant varieties and better agronomic practices to improve soybean and corn productivity, especially in the North, Northwest, West, and Southwest regions in the State of Parana.

\section{Materials and methods}

\section{Study region and crop data}

Losses in soybean and corn production in the spring-summer season were assessed in the State of Parana, Brazil, over a period of nine growing seasons (2007/2008-2015/2016). The regular growing season of soybean is between October and March, whereas that of corn is between September and February. Crop losses per region were estimated for each year using yield data obtained from the Secretariat of Agriculture and Supply, Department of Rural Economy (SEAB/DERAL). The state was divided into six regions (Northwest, North, West, Midwest, Southwest, and South) based on crop productivity (Fig. 1). The Coastal region was not included in the study due to the insignificant production of soybean and corn.

The Northwest region has sandy soils are with relatively low fertility, whereas all other regions have clay soils. In general, all the agricultural soils are very deep without any physical barriers for the root development (EMBRAPA, 2013). No-tillage is practiced, and corn is rotated with wheat or oats during the autumn-winter season.

\section{Meteorological data and analyses}

Meteorological data were obtained from weather stations of the Agronomic Institute of Paraná (IAPAR) and Meteorological Institute of Paraná (SIMEPAR) network located in Paranavaí (Northwest), Londrina (North), Palotina (West), Campo Mourão (Midwest), Pato Branco (Southwest), and Ponta Grossa (South) and used to estimate the 10-d climatic water balance in each region, considering an average available water of $12 \%$ (Heinemann et al., 2002; Costa et al., 2016) and an effective root system between 60$65 \mathrm{~cm}$. The available soil water capacity (AWC) was approximately $75 \mathrm{~mm}$ (Thornthwaite and Mather, 1955). The accumulated water deficit between November and January was used to estimate the annual and regional variations in productivity.

Previous studies showed that the highest productivity occurs under optimum water supply conditions and that water deficit is the main cause of soybean and corn losses in southern Brazil (Faria et al., 2015; Bergamaschi et al., 2004). Therefore, the year with the highest mean yield in each region was used as a reference to calculate the relative yield losses per year.

\section{Statistical analysis}

Yield losses in each region were correlated with the accumulated water deficit between November and January using a second-order polynomial regression model. The coefficients were adjusted by the least squares method and considered significant at $P<0.05$. Monetary losses were calculated between January and July, when farmers sell their production, using the market prices of each respective year in US\$.

\section{Conclusion}

Water deficit conditions in the transitional zone between subtropical and tropical climate in the State of Parana, southern Brazil, have a highly negative impact on soybean and corn yield. In terms of productivity, the South region of the state showed the highest stability, whereas the Northwest region the lowest stability in response to water deficit. Overall, more research is needed to improve soil and irrigation management and develop well-adapted cultivars to the environmental conditions of each region in the State of Parana, especially to the Northwest, North, West, and Southwest regions that are highly affected by water deficit.

\section{Acknowledgements}

The first author would like to acknowledge CAPES for supporting this study. We are thankful to IAPAR for providing the weather data and facilities to conduct this study.

\section{References}

Alberto CM, Streck NA, Heldwein AB, Buriol GA, Medeiros SLP (2006) Água no solo e rendimento do trigo, soja e milho associados ao El Niño Oscilação Sul Pesq Agropec Bras. 41(7):1067-1075.

AFDC (2016) Alternative Fuels Data Center, U.S. Dept. of Energy. World fuel ethanol production by country or region.

www.afdc.energy.gov/uploads/data/data source/10331/1 0331_world_ethanol_production.xlsx (Accessed January 10, 2017).

Aytav E, Kocar G (2013) Biodiesel from the perspective of Turkey: Past, present, and future. Renew Sustainable Energy Rev. 25:335-350.

Bergamaschi H, Dalmago GA, Bergonci Jl, Bianchi CAM, Müller AG, Comiran F, Heckler BMM (2004) Water supply in the critical period of maize and grain production. Pesq Agropec Bras. 39:831-839.

Bergamaschi H, Dalmago GA, Comiran F, Bergonci Jl, Müller AG, França S, Santos AO, Radin B, Bianchi CAM, Pereira PG (2006) Water deficit and yield in maize crop. Pesq Agropec Bras. 41(2):243-249.

Berlato MA, Farenzena H, Fontana DC (2005) Associação entre El Niño Oscilação Sul e a produtividade do milho no 
Estado do Rio Grande do Sul. Pesq Agropec Bras. 40(5):423-432.

ABIOVE-Brazilian Association of Vegetable Oil Industries (2016) Biodiesel: production by raw material-July 2016. http://www.abiove.org.br/site/index.php?page=statistics\& area=MTAtMi0x (Accessed January 10, 2017).

IBGE Brazilian Institute of Geography and Statistics (2016) Estatística da produção agrícola.

http://www.sidra.ibge.gov.br/bda/prevsaf (Accessed January 10, 2017).

Heinemann AB, Hoogenboom G, De Faria RT (2002) Determination of spatial water requirements at county and regional levels using crop models and GIS. An example for the State of Parana, Brazil. Agric Water Manage. 52:177-196.

Caviglione JH, Kiihl LRB, Caramori PH, Oliveira D (2000) Cartas climáticas do Paraná, IAPAR, Londrina: IAPAR (CD_ROM).

Costa ABF da, Araújo-Junior CF, Caramori PH, Yada IFU, Medina C de C (2016) Physical and hydraulic properties of a Latosol influenced by land use and management changes. Afr J Agric Res. 11(34):3217-3226.

CPC/NCEP/NOAA - Climate Prediction Center, National Centers for Environmental Prediction, National Oceanic and Atmospheric Administration (2016). Cold \&Warm Episodes by Season.

http://www.cpc.ncep.noaa.gov/products/analysis_monito ring/ensostuff/ensoyears.shtm (Accessed January 10, 2017).

EMBRAPA - Brazilian Agricultural Research Corporation. Brazilian system of soil classification (2013). EMBRAPA, Brasilia, $3^{\text {rd }}$. edition. $353 \mathrm{p}$.

Grimm AM, Ferraz SET, Gomes J (1998) Precipitation anomalies in Southern Brazil associated with El Niño and La Niña events. J Clim. 11:2863-2880.

Höök M, Tang, X (2013) Depletion of fossil fuels and anthropogenic climate change-A review. Energy Policy. 52:797-809.
IPCC Intergovernmental Panel on Climate Change (2014) Synthesis Report Summary for Policy makers. http://www.ipcc.ch/pdf/assessment-

report/ar5/syr/AR5_SYR_FINAL_SPM.pdf (Accessed August 17, 2016).

Markevicius A, Katinas V, Perednis M, Tamasauskiene M (2010) Trends and sustainability criteria of the production and use of liquid biofuels. Renew Sustainable Energy Rev. 14(9):3226-3231.

Morando R, Da Silva A, Carvalho L, Pinheiro M (2014) Déficit hídrico: Efeito sobre a cultura da soja. J Agron Sci. 3:114129.

Nesmith DS, Ritchie JT (1992) Effects of soil water-deficits during tassel emergence on development and yield component of maize (Zea mays). Field Crops Res. 28(3):251-256.

Pegorare $A B$, Fedatto E, Pereira SB, Souza LCF, Fietz CR (2009) Irrigação Suplementar no ciclo de milho "safrinha" sob plantio direto. Rev Bras Eng Agríc Ambient. 13(3):262271.

Rossetti LA (2001) Zoneamento agrícola em aplicações de crédito e seguridade rural no Brasil: aspectos atuariais e de política agrícola. Rev Bras Agromet. 9(3):396-399 (special issue: Zoneamento Agrícola).

SEAB/DERAL Secretariat of Agriculture and SupplyDepartment of Rural Economy (2015) Política Agrícola Safra 2014/2015.

http://www.agricultura.pr.gov.br/arquivos/File/deral/Prog nosticos/politicas_agricolas_2014_15.pdf> (Accessed August 15, 2016).

Thornthwaite CW, Mather JR (1955) The water balance. Centerton, NJ: Drexel Institute of Technology-Laboratory of Climatology. Publications in Climatology. VIII (1) 104p.

Wagner MV, Jadoski SO, Maggi MF, Saito LR, Lima AS (2013) Estimativa da produtividade do milho em função da disponibilidade hídrica em Guarapuava, PR, Brasil. Rev Bras Eng Agric Ambient. 17(2):170-179. 